\title{
CORPORATE CRIMINAL RESPONSIBILITY
}

\author{
HENRY W. EDGERTON
}

If a driver employed by a milk corporation sells watered milk in violation of a statute, either on his own initiative or on the order of the manager, the board of directors or the stockholders, may the corporation be convicted? If the manager of a coal corporation, either on his own initiative or on the order of the board of directors or the stockholders, combines with other concerns in unlawful restraint of trade, may the corporation be convicted? If guards in the pay of a mining corporation, either on their own initiative or on the order of the manager, the board of directors or the stockholders, direct a murderous gun-fire at a village in which striking employees live, in order to suppress the strike, may the corporation be convicted of murder?

It is submitted that the corporation should be criminally responsible in all the cases put. A corporation should be considered capable of any crime, and guilty of any crime if the human persons who commit the crime act in the course of their employment so as to make the corporation responsible in tort. The courts, if they have not fully reached this position, are approaching it. In the past 75 years they have progressed from very narrow views to or toward very broad views of corporate criminal responsibility. ${ }^{1}$ But it is not yet clear that corporations can commit all crimes; on the contrary, it is constantly assumed that they cannot; and it is not at all clear what human action is necessary to the commission of corporate crime.

\section{THE AUTHORITIES}

It used to be laid down that a corporation could not commit crime. ${ }^{2}$ Later, it was held that, though it might be criminally responsible for non-feasance, such as failure to repair roads or bridges, ${ }^{3}$ it could not be for misfeasance; ${ }^{4}$ though an exception was made of nuisance." But soon after the middle of the last

\footnotetext{
1 Two law review articles published in recent years have agreed in opposing the modern tendency toward broad responsibility. Canfield, Corporate Responsibility for Crime (1914) 14 Cor. L. REv. 469; Francis, Criminal Responsibility of the Corporation (1924) is Inc. L. REv. 305.

2 Anonymous, 12 ITod. 559 (K. B. 1701) (Holt, C. J.) ; 1 BL. Corrss. ${ }^{476}$, $* 477$.

3 Note (1912) 2 Brit. R. C. 231, at 232.

${ }^{4}$ State v. Ohio R. R., 23 Ind. 362 (1864); State v. Great Worlis Co., 20 Me. 41 (1841); Delaware Canal Co. v. Commonwealth, 60 Pa. St. 367 (1869).

5 State v. Morris R. R., 23 N. J. I. 360 (1852); Delaware Canal Co. v. Commonwealth, supra note 4 .
} 
century, the general notion that criminal misfeasance by a corporation is impossible practically disappeared. It has long been settled in most jurisdictions that corporations are capable of committing crimes in which the mental element is inconspicuous, or, as it is sometimes expressed, "the criminal intent is immaterial"; such as dealing in adulterated articles in violation of a statute. ${ }^{6}$ An intent to do the act which is prohibited may be attributed to a corporation.?

But several vestiges of the old tradition survive. First, if the crime involves "mens rea," in the sense that the mental element in the crime is conspicuous, the early Victorian tradition that a corporation cannot commit it ${ }^{8}$ has persisted, in some courts, into modern times. ${ }^{9}$ As Judge Hough has pointed out, this proposition regarding "mens rea" has usually been laid down by way of dictum; ${ }^{10}$ and most courts have advanced to the position that a corporation may be guilty of various forms of "mens rea." 11

${ }^{6}$ Commonwealth v. Graustein \& Co., 209 Mass. 38, 95 N. E. 97 (1011); Pearks, Gunston \& Tee, Ltd. v. Ward [1902] 2 K. B. 1.

7 United States v. John Kelso Co., 86 Fed. 304 (N. D. Calif. 1898).

8 State v. Morris R. R., supra note 5, at 370; Commonwealth v. Now Bedford Bridge, 2 Gray, 339, 345 (Mass. 1854).

${ }^{9}$ State v. Western N. C. R. R., 95 N. C. 602,610 (1886); Commonwealth v. Punxsutawney St. Ry., 24 Pa. Co. Ct. 25 (1899); Regina v. Gt. West. Laundry Co., 13 Man. 66 (1900) ; Pearks, Gunston \& Tee, Ltd. v. Ward, supra note 6 , at 11 .

10 United States v. MacAndrews \& Forbes Co., 149 Fed. 823, 836 (C. C. S. D. N. Y. 1906) ; cf. (1912) 2 Brit. R. C. 231 , at 238.

11 State v. Eastern Coal Co., 29 R. I. 254, 70 Atl. 1 (1908) (conspirncy to fix prices) ; Chicago, W. \& V. Coal Co. v. Illinois, 214 Ill. 421,73 N. E. 770 (1905) (same) ; Hough, J., in United States v. MacAndrews \& Forbes Co., supra note 10, at 835 (conspiracy to violate Sherman Act; ". . . defendant corporations claim that since in conspiracy evil intent is of the essence of the crime, inherent impossibility renders the accusation futile. I think this is but the remnant of a theory always fanciful and in process of abandonment") ; State v. Rowland Lumber Co., 153 N. C. $610,612,69$ S. E. (1910) (wilfully destroying buildings; ". . . that corporations cannot bo convicted of an offense where the intent is an ingredient is no longer tonable. They are as fully liable in such cases as individuals"); United States v. Union Supply Co., 215 U. S. 50, 30 Sup. Ct. 15 (1909). ("wilfully violating" oleomargarine law); People v. Rochester Ry. \& Light Co., 195 N. Y. 102, 88 N. E. 22 (1909); United States v. Nearing, 252 Fed. 223 (S. D. N. Y. 1918) ("wilfully obstructing" recruiting or enlistment service); United States v. American Socialist Soc., 260 Fed. 885, 887 (S. D. N. Y. 1919) (same; contention that a corporation cannot be guilty of an "evil purpose to do a wrongful act . . . successfully made in the earlier history of the law and, indeed, until comparatively recent times, has now been fully discarded"); American Socialist Soc. v. United States, 266 Fed. 212 (C. C. A. 2d, 1920), certiorari denied, 254 U. S. 637, 41 Sup. Ct. 12 (1920); Telcgram Newspaper Co. v. Commonwealth, 172 Mass. 294, 297, 52 N. E. 445, 446 (1899) (criminal contempt; "There is no more difficulty in imputing to a corporation a specific intent in criminal proceedings than in civil"); 
Second, the tradition that some particular crimes or classes of crimes cannot be committed by a corporation 12 has survived, though in attenuated forms. A federal court said in 1898: "Of course, there are certain crimes of which a corporation cannot be guilty; as, for instance, bigamy, perjury, rape, murder, and other offenses, which will readily suggest themselves to the mind." ${ }_{33}$ The United States Supreme Court said in 1909: "It is true that there are some crimes, which in their nature, cannot be committed by corporations." " In the same year the New York Court of Appeals said: "Of course, it has been fully recognized that there are many crimes so involving personal, malicious intent and acts ultra vires that a corporation manifestly could not commit them." 15 While the statements just quoted, and most similar statements, are dicta, there are decisions to the effect that a corporation cannot be guilty of homicide. ${ }^{16}$ There are, on the other hand, modern decisions that a corporation may be convicted of unlawfully causing a death, ${ }^{17}$ or manslaughter, ${ }^{23}$ or larceny. ${ }^{19}$

Third, it has often been asserted that a corporation cannot be guilty of a crime which is ultra vires; ${ }^{20}$ but the contrary has been held.21

People v. Star Co., 135 App. Div. 517, 120 N. Y. Supp. 498 (1st Dept. 1909) (criminal libel); Joplin Miercantile Co. v. United States, 213 Fed. 926 (C. C. A. 8th, 1914) (conspiracy to introduce liquor into the Indian country); State v. Lehigh Valley R. R., 90 N. J. L. 372, 103 Atl. $6 S 5$ (1917); 92 N. J. L. 261, 106 Atl. 23 (1919) (manslaughter), aff'd 94 N. J. L. 171, 111 Atl. 257 (1920) ; People v. Tyson \& Co., 50 N. Y. L. J. 1829 (N. Y. City Magistrate's Ct. 1914) (larceny).

12 In 1854 the Missachusetts court declared that a corporation could not be guilty of "treason or felony; of perjury or offenses against the perzon." Commonwealth $v$. New Bedford Bridge, supra note 8, at 345. Substantially the same language had been used by the Court of Queen's Bench in 1810. Queen v. G. N. of Eng. Ry., 9 Q. B. 315 (1846).

13 United States v. John Kelso Co., supra note 7, at 300.

14 New York Central R. R. v. United States, 212 U. S. 481, 494, 29 Sup. Ct. 304, 307 (1909).

15 People v. Rochester Ry. \& Light Co., supra note 11, at 105, 88 N. E. at 23.

${ }^{16}$ Commonwealth v. Illinois Central R. R., $152 \mathrm{Ky} .320,153$ S. W. 459 (1913) (manslaughter); Regina v. Gt. West. Laundry Co., supra note 9 (manslaughter); Commonwealth v. Punxsutawney St. Ry., supra note 9 (manslaughter) ; People v. Rochester Ry. \& Light Co., supre note 11 (manslaughter). The last decision turned on a statutory definition of the crime, and the court's argument is favorable to the view that, with no narrow definition in the way, a corporation might commit manslaughter.

17 Union Colliery Co. v. Queen, 31 Can. Sup. Ct. 81 (1900) (statutory). Is State v. Lehigh Valley R. R., supra note 11.

19 People v. Tyson \& Co., Inc., supra note 11.

20United States v. Alaska Packers Ass'n, 1 Alaska, 217 (1001); 1 IICClatn, Criminal Latw (1897) § 184; 1 Bishop, Criaminal Law (9th cd. 1923) $\S \S 417,418,422$.

21 Louisville Ry. v. Commonwealth, $130 \mathrm{Ky} .73 \mathrm{~S}, 114 \mathrm{~S}$. W. 343 (1908); 
Some cases, chiefly early ones, hold that corporations are not within the meaning of general words like "any person," "whoever," etc., in criminal statutes. ${ }^{22}$ The rule has survived into modern times in a few states; ${ }^{23}$ but it is now very generally held that such words include corporations, and that criminal statutes employing such words are accordingly applicable to corporations unless a contrary intent appears. ${ }^{24}$ Sometimes general construction statutes aid in reaching this conclusion. ${ }^{20}$

If, as in the case of "felonies," the only punishment available for a given crime is one which cannot be inflicted upon a corporation-specifically, death or imprisonment-it is generally laid down that the corporation cannot be convicted or indicted.20 But it appears that the corporation may commit the crime; for an individual may be convicted of aiding and abetting the corporation to commit it, or conspiring with the corporation to commit it, though there is no way of punishing the corporation.27 And the corporation itself may be convicted of a crime for which the punishment provided is fine or imprisonment, ${ }^{28}$ or even fine and imprisonment, ${ }^{29}$ though it is evidently impossible to enforce the provision for imprisonment. The whole difficulty may be readily removed by a statute which makes it clear

Union Colliery Co. v. Queen, supra note 17; $c f$. the dictum in Nat'1 Bank v. Graham, 100 U. S. 699,702 (1879): "Corporations are liable for every wrong they commit, and in such cases the doctrine of ultra vires has no application."

22 State v. Cincinnati Fertilizer Co., 24 Ohio St. 611 (1874).

${ }^{23}$ State v. Terre Haute Brewing Co., 186 Ind. 248, 115 N. E. 772 (1917); Judge Lynch Book Co. v. State, 84 Tex. Cr. App. 459, 208 S. W. 626 (1919).

24 United States v. Union Supply Co., supra note 11; United States v. American Socialist Soc., supra note 11, at 887; United States v. John Kelso Co., supra note 7; United States v. N. Y. Herald Co., 159 Fed. 296 (S. D. N. Y. 1907); State v. Creamery Co., 83 Kan. 389, 111 Pac. 474 (1910); United States v. Alaska Packers Ass'n, supra note 20; United States v. Ames Co., 2 Alaska, 74 (1903); Overland Cotton Mill Co. v. People, 32 Colo. 263, 75 Pac. 924 (1904); State v. Baltimore \& Ohio R. R., 15 W. Va. 362 (1879):

25 U. S. Rev. Stat. (2d ed. 1878) § 1: “ . . . the word 'person' may oxtend and be applied to partnerships and corporations." English Interprotation Act (1889) 52 \& 53 Vict. c. 63, \$ 2 (1): "In the construction of every enactment relating to an offense ... whether contained in an Act passed before or after the commencement of this Act, the expression 'person' shall, unless the contrary intention appears, include a body corporate."

26 State v. Truax, 130 Wash. 69, 226 Pac. 259 (1924).

${ }_{27}$ United States v. Van Schaick, 134 Fed. 592, 602 (C. C. S. D. N. Y. 1904); Cohen v. United States, 157 Fed. 651, 653 (C. C. A. 2d, 1907).

${ }^{28}$ Southern Ry. $\nabla$. State, 125 Ga. 287, 54 S. E. 160 (1906); (1924) 33

A. L. R. 1211, n.

29 United States v. Union Supply Co., supra note 11; Commonwealth v. Pulaski Co. Agx'l Ass'n, 92 Ky. 197, 17 S. W. 442 (1891). 
that, whatever the crime, when the defendant is a corporation a fine may be imposed. ${ }^{30}$

The question in what relation the human criminals must stand to the corporation in order that their crime shall be its crime has received little attention. The question is often altogether ignored in cases in which it would seem to be directly involved.:2 A conspicuous example of this tendency is Grant Bros. Construction Co. v. United States, ${ }^{32}$ in which a jury, instructed to decide whether "the company" knew that the statute was being violated, apparently received very little light from the court upon the question whose knowledge would be "the company's" knowledge for this purpose. It is clearly not necessary that either stockholders or directors in meeting authorize or approve the criminal act; if this were required, there would be few corporate crimes, as the desired result can always be brought about without formal action. Informal authority, as by silent acquiescence in similar crimes, is clearly enough. ${ }^{33}$ Few courts, if any, have thought it necessary that the stockholders be in any way involved. It is sometimes assumed that the directors must be. $^{34}$ Sometimes it is assumed that either the stockholders or the directors must be. ${ }^{35}$ It has been suggested that in regard to crimes in which a "criminal mind" is essential, the corporation should be identified with its "governing offcers." is But in many cases the action of an agent or servant of the company,

30 N. Y. Penal Law (Cahill, 1923) § 1932, provides that "In all cases where a corporation is convicted of an offense for the commission of which a natural person would be punishable with imprisonment, as for a felony, such corporation is punishable by a fine of not more than five thousand dollars."

31 E. g., State v. Workers' Socialist Pub. Co., 150 Minn. 408,185 N. W. 931 (1921) ; Postal Telegraph-Cable Co. v. Charlottesville, 126 Va. 800, 101 S. E. 357 (1919).

3213 Ariz. 388, 114 Pac. 955 (1911).

${ }_{33} C f$. State v. Baltimore \& Ohio R. R., supra note 24.

31 ". ... the intention of its directors that the prohibitcd act should be done is imputed to the corporation itself." United States v. John Kelso Co., supra note 7 , at 306.

In imposing criminal responsibility the law should look "rather to the corporation at whose instance and for whose benefit the wrong is perpetrated, than to the individual directors by whose order the wrong was done." State v. MIorris R. R., supra note 5, at 369.

35 In American Socialist Soc. v. United States, supra note 11, at 214, the jury was charged not to convict the corporation unless they found that the men who acted "were authorized by the board of directors or the membership of the corporation to obstruct the recruiting or enlistment service."

In People v. Sheffield Farms Co., 225 N. Y. 25, 121 N. E. 474 (1018) and State v. Baltimore \& Ohio R. R., supra note 24 , it is not clear whether participation of the directors, or of the directors or stoclhholders in the alternative, is required.

36 Notes (1914) 27 HARv. L. REv. 589. 
in the course of his employment, is treated as making the corporation guilty. ${ }^{37}$

The statement of the Attorney General of Rhode Island in 1908,38 that "The tendency of the present time is to hold corporations responsible, criminally as well as civilly, for all acts committed by their agents, having any relation to the business of the corporation" (i.c., to that part of its business which is entrusted to those agents) is clearly true today.

\section{REASONS FOR RESPONSIBILITY}

The reasons for imposing upon corporations criminal responsibility for their agents' acts are the same reasons which justify treating the same acts as criminal in the individual actors. Whatever social purpose (if any) tends to be served by punishing or threatening to punish the individual who does a given act, tends also to be served by punishing or threatening to punish the corporation in the course of whose business he does it. The argument against corporate criminal responsibility, that the corporation cannot itself be "guilty" and therefore should not be punished, rests on the tacit assumption that the aim of criminal law is retributive or retaliative, which is to say vindictive or vengeful; consists, in other words, in the pleasure which some persons derive from the infliction of pain upon those whom they conceive to deserve it. Corporate irresponsibility is a survival from a time when that was more broadly and clearly true than it is today. No doubt most of us occasionally experience this sadistic sort of impulse, and no doubt it still underlies much of our criminal law. It is gratified in many instances rather

37 Overland Cotton Mill Co. v. People, 32 Colo. 263, 75 Pac. 024 (1904) (employing child labor; the agent had been forbidden to commit the crime). Acc.: State v. Louisville \& N. R. R., 91 Tenn. 445, 19 S. W. 229 (1892) (obstructing highway). [Contra: as to effect of violation of orders, John Gund Brewery Co. v. United States, 204 Fed. 17 (C. C. A. 8th, 1913) (selling liquor)]. Southern Express Co. v. State, 1 Ga. App. 700, 58 S. E. 67 (1907) (delivering liquor); Standard Oil Co. v. State, 117 Tenn. 618, $100 \mathrm{~S}$. W. 705 (1907) (anti-trust law); New York Central R. R. v. United States, supra note 14 (Elkins Act-clear intent of statute); People v. Star Co., supra note 11 (criminal libel); Telegram Newspaper Co. v. Commonwealth, supra note 11 (criminal contempt); State v. Firemen's Fund Ins. Co., 152 Mo. 1, 52 S. W. 595 (1899) (anti-trust law); People v. Rochester Ry. Light Co., supra note 15.

Cf. United States v. N. Y. Herald Co., supra note 24 (knowingly mailing unmailable matter); State v. Worker's' Socialist Pub. Co., supra note 31 (publishing forbidden doctrine) ; Postal Telegraph-Cable Co. v. Charlottesville, supra note 31 (doing business without license).

These cases cannot be explained away on the ground, suggested in State v. Baltimore \& Ohio R. R., supra note 24 , at 387 , that the criminal act of the agent was one "which from its nature must have been approved by the corporation, such as the erection of a depot in a public road."

38 State v. Eastern Coal Co., supra note 11, at 267, 70 Atl. at 7. 
by the punishment of the individual criminal than of the corporation for which he acts.

But we are coming to accept the idea that the infliction of harm is not in itself a good; that the only decent purpose of criminal law, as of any law, is to accomplish something useful to man. As the gratification of the primitive capacity for delight in suffering cultivates a tendency to inflict it, enjoyment by others of the criminal's pain is not an unmixed benefit to man; and it appears to be the only benefit which can commonly result from imposing criminal penalties upon an individual, and cannot commonly result from imposing them also upon the corporation for which he acts. As the criminal responsibility of corporations, when it exists, is not exclusive or alternative, but cumulative, with the responsibility of the individual criminals, there is no competition between the two responsibilities and the question which is commonly the more effective in preventing corporate business from being conducted in criminal ways is unimportant. The chief civilized purpose of criminal law is deterrence-the prevention of acts which are conceived to injure one social interest or another. The question is not whose mind is "guilty," but whose responsibility will serve this deterrent purpose (without disproportionate sacrifice of other social interests).

It seems evident that this purpose is further served if corporate criminal responsibility is added to the criminal responsibility of the corporation's representatives. If the corporation itself is immune, it often stands to gain rather than to lose by the commission of crime in its business, and directors, stockholders and agents, from loyalty to it or in the hope of bettering theix own position in it or through it, may talie a chance of personal responsibility for the sale of corporate advantage. On the other hand, if the proposed crime involves a prospect of loss, by fine, to the corporation, and consequent injury to the actor's position with it or investment in it, this prospect added to the chance of personal responsibility may deter him. In sustaining the conviction of a railroad corporation for rebating, the Supreme Court has said:

"It is a part of the public history of the times that statutes against rebates could not be effectually enforced so long as individuals only were subject to punishment for violation of the law, when the giving of rebates or concessions enured to the benefit of the corporations of which the individuals were but the instruments. This situation, developed in more than one report of the Interstate Commerce Commission, was no doubt influen-

39 New York Central R. R. v. United States, supra note 14; United States v. MacAndrews \& Forbes Co. supra note 10; Crall \& Ostrander v. Comm., 103 Va. 855,49 S. E. 683 (1905). 
tial in bringing about the enactment of the Elkins Law, making corporations criminally liable." 40

It may be suggested with force that people object quite as strongly to direct as to indirect injury to themselves, and quite as strongly to deprivation of life or liberty as to the economic loss which is all that can reach them through the punishment of a corporation. But, in many cases, economic loss is all that can fall upon the individual actor, though he be prosecuted personally, since the only punishment provided for great numbers of offenses is a fine; and with a little zeal on the part of prosecuting officers, the likelihood of the theoretically available punishment (if any) being actually inflicted may be made so much greater in the case of the corporation as to constitute not only an appreciable and additional deterrent, but in many instances a stronger one than the direct penalty to which the individual is exposed.

There are several reasons for this potentially greater likelihood. In the first place, it may on occasion, be clear enough that some individuals have committed a crime for corporate purposes, and yet not clear who those individuals are. It is moreover relatively difficult to apprehend and prosecute a number, particularly a large number, of individuals, even if their identity is known; the corporation is always readily available. And the individuals may be financially so irresponsible as to have nothing to fear from a fine, ${ }^{41}$ while the assets of the corporation may be abundant. Finally, juries-as has long been notorious in civil cases-are not so reluctant to find corporations guilty as to find individuals guilty. The Nearing case ${ }^{42}$ illustrates this in the criminal field. Scott Nearing and the American Socialist Society were jointly indicted for wilfully obstructing the recruiting or enlistment service of the United States. The alleged means of obstruction was the publication of a book or pamphlet called "The Great Madness." The jury was instructed to acquit the corporation unless it found that the individuals who acted were authorized by the board of director's or by the membership of the corporation to obstruct the recruiting or enlistment service. There was no direct evidence that the members of the corporation, or its board of directors,

${ }^{40}$ New York Central R. R. v. United States, supra note 14, at 495, 29 Sup. Ct. at 307. The Elkins Act provides: " . . . the act, omission, or failure of any officer, agent, or other person acting for or employed by any common carrier . . . shall in every case be also deemed to be the act, omission, or failure of such carrier as well as that of the person." 32 Stat. 847, (1903) U. S. Comp. Stat. (1916) § 8597 (2).

41 Apart from the risk, in some jurisdictions, of commitment in default of payments. See 16 C. J. 1367.

42 United States v. Nearing, supra note 11; United States v. American Socialist Soc., supra note 11. 
or even its publication committee, authorized the publication. The only evidence against the corporation seems to have been that certain of its officers authorized the publication, that Nearing was paid with corporate funds, and that it was reported at a corporate meeting that two pamphlets by Nearing had been published. On the other hand, it was not disputed that the book was written by Nearing. Yet the jury acquitted Nearing and convicted the corporation; and this result was sustained on appeal. As the district court observed:

"In indictments for crime, where human beings are jointly tried with corporations, the human interest naturally centers around the living individual. During a trial the corporation is a sort of abstraction, and seems rather a secondary figure. The human being may lose his liberty if convicted, while the worst that can happen to the corporation is the imposition of a fine. When, therefore, the jury rendered its verdict, the first impression was one of inconsistency and compromise." 43

Corporate criminal responsibility tends to prevent crime not only by influencing the corporation's representatives of all degrees to abstain from conducting its business in unlawful ways, but also by influencing those of higher or more remote degree to restrain subordinates. Stockholders who know nothing about the business of a corporation incur no personal responsibility if it is in fact conducted in a criminal way. A stockholder may examine the corporation's books; a stockholder may restrain the corporation by injunction, if necessary, from doing a criminal act; but as criminal acts, which impose no responsibility upon him, may be very profitable to it, the law offers him little inducement-if the corporation also is immune-to prevent crime by the exercise of his powers of investigation and restraint. So far as it makes the corporation criminally responsible, the law supplies the stockholder with a strong motive for seeing that its business is lawfully conducted. Similarly, directors, managers and superior agents are necessarily more inclined to encourage or ignore criminality on the part of their subordinates, when the subordinates alone are subject to punishment, than when their crimes involve a risk of injury to the corporation, and through it to the directors and managers themselves.

Why should a distinction be made between the criminal and the civil responsibility of a corporation for the acts of its agents? The simple and orderly course would seem to be to make no distinction; the burden of proof may be said to rest, logically, upon the proponents of a distinction, though we are so accustomed to the idea of some distinction that the proposal to complete its

13 United States v. Nearing, supra note 11 , at 888. 
abolition carries the practical burden which always rests upon the proponents of change. What differences are there between crimes and torts which require or justify a narrower corporate responsibility for crimes than for torts? It is said that crimes are injuries to the state, the public, or society, while torts are injuries to individuals. But many crimes are torts and many torts crimes. Nothing can injure society, or the public, without injuring a greater or less number and proportion of individuals. The same thing is true of the "state"; which means either the government or the society that is governed. Since governments consist of human beings and exist to serve human purposes, an injury to the government is an injury to the individuals by or for whom it is conducted. It is true, of course, that an act may injure the government, in the sense of the minority by or for whom it is conducted, and yet be harmless or beneficial to society, in the sense of the majority; but this does not militate against the proposition that it is impossible to injure either society or the government without injuring individuals. Conversely, an injury to individuals is not often made a tort unless it is felt to have a tendency to injure society. Not only murder, rape and arson, but restraint of trade and the sale of adulterated milk, injure society because they injure individuals; and exactly the same is true of personal injuries, deceit, defamation, malicious prosecution and unfair trade. The supposed difference in nature between crimes and torts is a difference in emphasis or point of view on the one hand, and in procedure on the other. ${ }^{44}$ But even if it were true that crimes injure only society and torts only individuals, would it follow, or even tend to follow, that the criminal responsibility of corporations should be narrower than their civil responsibility? Do the interests of society deserve less protection than the interests of individuals?

\section{THE INNOCENT STOCKHOLDER}

It is true, of course, that the influence which a small stockholder in a large corporation is capable of exerting is commonly infinitesimal. It is also true that in many and perhaps most instances, crimes, the commission of which cannot be prevented by the prospect of personal responsibility, will not be prevented by the prospect of corporate responsibility. But corporate re-

44 ".. the real distinction between a tort and a crime is to be sought for, not in a difference between their tendencies, but in the difference between the methods by which the remedy for the wrong is pursued." $16 \mathrm{C}$. J. 55. "An offense which is pursued at the discretion of the injured party or his representative is a Civil Injury. An offense which is pursued by the Sovereign or by the subordinates of the Sovereign, is a Crime." 1 AusTiN, JURISPRUDENCE (3d ed. 1869) Lect. 17, quoted in 16 C. J. 55 from 1 Coolex, TORTS (3d ed. 1906) *96. 
sponsibility inevitably tends to supply an additional deterrent, and this additional deterrent cannot fail to be effective in a substantial number of instances. It should accordingly be imposed unless its imposition will do harm as serious as the good which it is clearly capable of accomplishing. The only serious harm which it can do, consists in the injury to those really innocent stockholders who have nothing to do with the crime and no real opportunity of preventing it. This injury is regrettable; but it is the same sort of injury which results to the same innocent stockholders from imposing tort, or contract, or workmen's compensation responsibility on the corporation. Equally in the criminal case and in the other cases, the balance of advantage seems to require subordinating their interest to the general interest. However "innocent" the owners of the corporate enterprise may be, the general interest requires that the burden of torts ${ }^{4}$ and industrial accidents should fall upon them rather than upon the casual victim, and it requires, similarly, that corporate representatives be deterred, so far as corporate responsibility can deter them, from conducting the business in criminal ways. It is true that the conspicuous social interest involved is not identical in the two cases; that it consists in compensation in the one case, and prevention in the other; but the social interest in prevention is quite as great as the social interest in compensation, and therefore quite as capable of outweighing the private interest of individual stockholders. Mioreover, the difference between the social interests involved in the two cases is hardly so marked as the traditional way of looking at them assumes; for tort responsibility serves at least a secondary purpose of deterrence, and it is arguable that criminal responsibility in the form of a fine may often serve a secondary purpose of compensation. ${ }^{45}$

45 An exception was once made of intentional torts. Orr v. Banls of United States, 1 Ohio, 36 (1822); Vanderbilt v. Richmond Co., 2 N. Y. 470 (1849) ; Eastern Counties Ry. v. Broom, 6 Ex. 314 (Ex. Ch. 1851). But the responsibility of employers was long ago extended to them, regardless of their being or not being also crimes. Fifth Ave, Banli v. Forty-Sccond St. Co., 137 N. Y. 231, 33 N. T. 378 (1893) (forgery); Hamlyn v. Houston \& Co. [1903] 1 K. B. 81 (bribery by agent of partnership); Nat'l Banls v. Graham, supra note 21, at 702. And "the liability of the employer for the deliberate acts of his servant seems to have been introduced in the special case of corporations. All the earlier reported cases . . . are cases of . . . companies." BaTY, Vicarious LIABIIITY (1916) 85. It has even been clear for some time that corporations may be responsible for exemplary or punitive damages on account of the torts of their servants. 2 Monuwetz, Printi CORPORATIONs (2d ed. 1886) $\$ 729$.

46 I.e., not vengeance, but economic reparation to society for the injury which the crime is conceived to have inflicted upon it. As the New Yor: Court of Appeals has put it, " . . . the duty to make reparation to the state for the wrongs of one's servants when the reparation does not go beyond the payment of a moderate fine, is a reasonable regulation of the right to do business by proxy." People v. Sheffield Farms Co., oupra 
It is sometimes assumed that a crime cannot be a corporate act unless it is authorized or ratified by the directors or the stockholders. A minor objection to this view is that such action, even if it has occurred, may be very difficult to prove; it is not likely to be set out in the minutes. ${ }^{47}$ But it might as well be argued that, as neither directors nor stockholders can legally authorize the commission of a crime, a crime can never be a corporate act; which is as much as to say that all crime, corporate and non-corporate, is impossible, since no one can commit crime legally. The machinery for the commission of corporate crime, as of any crime, is necessarily extra-legal. If $A$ has entered into an intra vires contract in the name of a corporation, the directors could lawfully authorize him to do so, and the question of its responsibility is the question of his authorization. But if $\mathrm{A}$ has committed either a crime or a tort in the course of the corporation's business, no one could lawfully authorize him to do so, and the question of the corporation's responsibility is the broad question of policy; will the general interest be served, on the whole, by imposing it? Analogies based upon the machinery by which legal acts may be legally authorized are scarcely material. If $\mathrm{A}$ has committed a tort in the course of the corporation's business, there is clearly no necessity that directors or stockholders shall have authorized the commission of the particular tort, or of a class of torts to which it belongs, or of torts in general, in order to make the corporation responsible; an authority to A to do a part of the corporation's work incidentally to which the tort was done, is enough to make it responsible. If in the doing of the same work A commits a crime, his want of authorization is no greater and the reasons of policy for holding the corporation are no less. In the language of the United States Supreme Court, "We see no valid objection in law, and every reason in public policy, why the corporation, which profits by the transaction, and can only act through its agents and off-

note 35 , at $32,121 \mathrm{~N}$. E. at 477 . The conduct of enterprises leads occasionally to crimes as inevitably, though not so frequently, as to torts or industrial accidents. Some of the resulting social burden may well be imposed upon the concern, and so ultimately upon the individuals, who carry on and profit from the business. The business which has injured society may well confer a benefit upon society through the payment of a fine. The risk of loss may appropriately fall where the chance of profit lies. That the notion of economic reparation for crime is unconventional is not all that can be said against it; such reparation may be inadequate and is necessarily inaccurate. But this is equally true of compensation to individuals for many torts, such as defamation or personal injuries. It does not follow that it is not worth while for the law to attempt compensation.

17 Cf. Limpus v. Gen. Omnibus Co., 1 H. \& C. 526 (Ex. Ch. 1862) ; Stato v. Baltimore \& Ohio R. R., supra note 24 . 
cers, shall be held punishable by fine because of the knowledge and intent of its agents. . . . " 48

If the business in which the crime is committed is ultra vires, it is reasonable to hold that neither the business nor anything in furtherance of it is done by the corporation unless the stockholders have authorized or acquiesced in the business; but if they have, its ultra vires character furnishes no logical reason for relieving the corporation from responsibility for the crime. Its ultra vires character then means no more than that the corporation was not authorized by the state to commit the crime; but, obviously, no one is authorized by the state to commit any crime. The courts have had to abandon at various points the old notion that ultra vires action is impossible. Ultra vires torts and ultra vires transfers of property create rights and liabilities. There is no reason for a distinction in this respect between torts and crimes.

The consequences of criminal responsibility, in the case of a corporation, are neither different in kind from the consequences of civil responsibility, nor necessarily greater in degree. The contrary notion results from confusing the corporation's situation with that of an individual. In the case of an individual, while tort responsibility commonly involves no buxden but on economic one, many sorts of criminal responsibility may involve his liberty, and some may involve his life. Even if the sentence is a fine, he may in many jurisdictions be committed until it is paid. ${ }^{49}$ Furthermore, he is more likely to suffer opprobrium from a criminal prosecution than from a civil one; and in the case of some crimes, the odium which results from conviction, or even prosecution, is great. These may be good reasons for refusing to make the individual's criminal responsibility for his agents' acts as broad as his civil responsibility. But such distinctions are nearly or quite irrelevant when the defendant is a corporation. A corporation's conviction of crime, no matter what crime, can neither hang any one nor deprive any one of a day's liberty. Neither can it, normally, injure any one's reputation; certainly it can seldom affect the reputations of those persons connected with the corporation who are unconnected with the crime. The consequences of a corporation's criminal responsibility as of its civil responsibility are purely economic. This is true even if the corporation, in addition to being fined, is deprived of its charter, or suffers a loss of popularity and patronage. To the really innocent stockholder it is quite immaterial whether his corporation is found guilty of a crime, a tort,

$48 \mathrm{New}$ York Central R. R. v. United States, sugra note 14 , at 495,29 Sup. Ct. at 307.

49 See 16 C. J. 1367. 
or a breach of contract; in each case he stands to suffer a money loss, and a money loss only.

\section{CORPORATE "GUILT"}

It is said that crime involves guilt, that guilt is personal, and that there should therefore be no vicarious criminal responsibility; that a corporation cannot itself have a "guilty mind," and should not be criminally responsible for the conduct of others, whatever their relation to it. This argument involves a number of very doubtful premises, besides the premise that the purpose of criminal law is the vindictive one of punishing the "guilty." It assumes, in the first place, that the corporation's representatives are "others" than the corporation as clearly and completely as a human principal and his agent are distinct beings. Without undertaking to contribute to the debate over the real or fictitious character of the corporate entity, it may be suggested that this assumption is not wholly true on the basis of either the reality theory or the fiction theory. So far as the separate corporate entity is a fiction, and the corporation is in fact nothing but its stockholders, it follows at once that the acts and thoughts of the directors and agents are not strictly those of the corporation, but also that the acts and thoughts of the stockholders (which relate to its business) are strictly those of the corporation. On the other hand, so far as the separate entity is a reality, it would seem to follow that what stockholders, directors, officers, agents, or servants of the corporation do, in the course of their employment, is actually done by it. A human being may speak words or make motions himself, or he may employ an agent who does so for his purposes; there is, then, a clear distinction of fact between his action and his agent's. But a corporation, if it is an entity distinct from its stockholders, can neither move nor speak except in and by entities other than itself; and there is, therefore, no distinction at all between its speech or motion and that of its representatives in the course of its business. Though qui facit per alium facit per se, as applied to a human principal, is a pure fiction, it does not follow that it is fictitious to say that the acts of corporate representatives are the acts of the corporation. The alternative, if the corporation is a reality, is to say that it exists but cannot act; and if it is admitted to exist, it is hard to imagine a reason for denying that it can act.

The tradition that the physical movements of a corporation's representatives may, but their mental states may not, be attributed to it for criminal purposes, ${ }^{50}$ seems as inept as it is per-

50 " . . public policy certainly does not demand that a porson or association should be punished by the State, through criminal proceedings, on account of a wrong committed by another. This would bo contrary to 
sistent. There is no occasion for such a distinction between the various parts of the human animal; if what his hands do may properly be attributed to the corporation for which he acts, what his brains do may be attributed to it with equal propriety. ${ }^{\text {st }}$ This obsolescent distinction is parallel to the obsolete one to the effect that a corporation, having no mouth to speak with, could not contract orally, but only by deed. The law came to recognize that corporations are as well (or ill) equipped with mouths as with hands; it is coming to recognize that they are as well equipped with brains as with either. In the same sense and to the same extent that they can talk and strike, they can desire and plan.

It is sometimes assumed that there are limits of some less definite sort to vicarious action, and that this precludes the commission of some crimes, like murder, bigamy, rape $=2$ and perjury, by corporations. Why murder is commonly included in this category is not apparent, as it is notorious that a human being may commit murder without himself handling the weapon. Moreover, any distinction between acts which can, and acts which cannot, be done vicariously is illogical; logically, everything or nothing can be done vicariously. A may fire the gun which kills $X$, and A may swear falsely. B may be emotionally, physically and geographically incapable of firing the gun; but if he procures $A$ to fire it (to kill $X$ ), $B$ is guilty of murder. If $B$ procures A to swear falsely, there is no good reason why $B$ should not be deemed guilty of perjury. There is no logic, there is only habit, in saying that B strikes the blow which A strikes at his instigation, but that he does not take and violate the oath which $\mathrm{A}$ takes and violates at his instigation. The proposition about the blow is true only in a figurative sense, and in the further sense that it is useful to hold $B$ responsible for A's blow. The figure and the responsibility would be just as appropriate

the natural sense of justice. Hence it is held that where the commission of a crime involves the intention of the offender, this intention cannot be imputed by means of a fiction; actual intention is required.

"It follows, therefore, that a corporation cannot be charged criminally with a crime involving malice, or the intention of the ofiender. Even though the corporators themselves should unanimously join, with malice aforethought, in committing a crime as a corporate act, yet the malice would be that of the several members of the company, and not actually one malicious intention of the whole." 2 IORAWETz, op. cit. supro note 45, at $\S 732$. But where "the crime consists of the act alone, without regard to the intention with which it was committed . . . there is no difficulty in attributing an offense of this character to a corporation, since it may be committed entirely through the company's agents." Ibid. $\$ 733$.

" . . corporations are not properly indictable for erimes involving a criminal state of mind." Canfield, op. cit. sipra note 1, at 480.

51 Cf. supra note 11 .

52 The courts have held that rape is not too personal to be committed vicariously, and that it may accordingly be so committed by persons who 
in the case of the oath. If it has not been customary to call B's offense perjury, but subornation of perjury, this is an accident which has no basis in the nature of things. While corporations are not apt to commit rape, there is no inherent difficulty about it. So the practice of law is felt to be so personal that corporations should not engage in it; ${ }^{53}$ yet the possibility of their doing so is necessarily recognized by the very statutes and decisions which condemn it. It is submitted that there is no crime which corporations should be regarded as incapable of committing, unless one created by a statute which is clearly aimed at human beings only.

Moreover, the assumption that crime involves "guilt" is quite erroneous. The proposition "guilt is personal," and the argument against vicarious responsibility which is based upon it, evidently contemplate "guilt" in some moral sense; but the presence or absence of guilt in any such sense is generally or always immaterial to the question of an individual's criminal responsibility. It is familiar that great numbers of statutory crimes involve no mental element more evil than the intent to do the act which the statute prohibits; and ignorance of the prohibition is, of course, no defense. It is also true, if somewhat less familiar, that the actor may be responsible though he did not know, and had no means of knowing, that the act he committed and the act which the statute prohibited were in fact the same. ${ }^{.4}$ Thus, a man may be guilty of adultery though he does not know that the woman with whom he has intercourse is married; ${ }^{\text {to }}$ of selling ${ }^{56}$ or transporting ${ }^{57}$ intoxicating liquor, though he does not know that the liquor is intoxicating; of knowingly depositing obscene matter in the mails, though in his opinion the matter he deposits is not obscene. ${ }^{5 s}$ Courts have even permitted entirely "guiltless" human principals or superiors to be convicted of vari-

cannot commit it directly, including the victim's husband (Audloy's Case, 3 How. St. Tr. 401 (1631); Re Kantrowitz, 24 Calif. App. 203, 140 Pac. 1078 (1924); the cases are collected in (1922) 18 A. L. R. 1064 n.) ; or a woman (State v. Jones, 83 N. C. 605 (1880); the cases are collected in a note in (1920) 5 A. L. R. 782: "Criminal responsibility of one cooperating in offense which he is incapable of committing personally"). Impotence is no defense to a charge of aiding another to commit rape. Law v. Commonwealth, 75 Va. 885 (1881).

53 Matter of Co-op. Law Co., 198 N. Y. 479, 92 N. E. 15 (1910).

54 Brown v. State, 7 Pen. 159, 74 Atl. 836 (Del. 1909) (harboring a female under 18 for sexual intercourse; reasonable belief that she was over 18 no defense); Commonwealth v. Smith, 166 Mass. 370, 44 N. E. 503 (1896) (being present where gambling implements are found; indictments need not charge defendant knew of the presence of the implements).

55 Commonwealth v. Elwell, 2 Metc. 190 (Mass. 1840).

56 Commonwealth v. Hallett, 103 Mass. 452 (1869).

57 Commonwealth v. Mixer, 207 Mass. 141, 93 N. E. 249 (1910).

58 Rosen v. United States, 161 U. S. 29, 41, 16 Sup. Ct. 434, 438 (1896). 
ous statutory crimes, ${ }^{59}$ and some common-law crimes. ${ }^{\text {ca }}$ But it is said that, while most statutory crimes and some common-law crimes may properly be attributed to a corporation, because they involve no "guilty mind," most common-law and some statutory crimes involve a guilty mind or "mens rea." This is true only in a technical or figurative sense. These familiar words undoubtedly have a strong moral connotation, but it is a connotation at variance with the facts. There is probably no crime which has as one of its necessary elements either hate, or envy, or ill-will, or selfishness, or sense of wrong-doing, or contempt for law, or any generally harmful or generally reprobaţed ("immoral") mental characteristic. The so-called "guilty mind" of criminal law means only those highly various particular mental states which are constituent elements in various particular crimes. ${ }^{62}$ No

59 Bond v. Evans, L. R. 21 Q. B. D. 249 (1888) (suffering gaming to be carried on); State v. Gilmore, 80 Vt. 514, 68 Atl. 05s (100S) (Eelling liquor to minor; defendant had forbidden such sale); State v. Worliers' Socialist Pub. Co., supra note 31, at 411, 1S5 N. Wr. at 033 (editing, issuing or knowingly circulating certain doctrine; defendant, the managing cditor of a paper, "exercised no supervision over the page on which the article in question appeared, and . . . did not see it until after it was published"). Contra: People v. Parks, 49 Mich. 303, 13 N. W. 613 (1SS2) (sale of liquor to drunkard); Kearley v. Tonge, 60 L. J. @. B. 159 (1891) (sale of adulterated food).

60 Rex v. Gutch, 1 MTood. \& NI. 433 (Nisi Prius 1829) involved an indictment of individuals, the proprietors of a newspaper, for a libel published in the paper. There was no evidence that the men lnew anything about the libel. Lord Tenterden, C. J., charging the jury, at 497: "a proprictor of a newspaper who is not shown to talke, or who can show that he took no part in the publication of the newspaper, and of the libel in question," is criminally responsible. "But it is said that this is a differcnt principle from that which prevails in all other criminal cases; but thi3 does not appear to me to be so; the rule secms to me to be conformable to principle, and to common sense; surely a person who derives profit from, and who furnishes means for carrying on the concern, and entrust the conduct of the publication to one whom he selects, and in whom he confides, may be said to cause to be published what actually appars, and ought to be answerable, although you cannot show that he ras individually concerned in the particular publication. It would be excecdingly dangerous to hold otherwise, for then an irresponsible person might be put forward, and the person really producing the publication and without whom it could not be published, might remain behind and escape altogether."

See also Queen v. Stephens, L. R. 1 Q. B. 702 (1866) (public nuisance, committed by defendant's workmen contrary to his orders, but in apparent scope of employment).

Gi Speaking of the phrase "non est reus, nisi mens sit rea," Sir James Stephen, J., said, in Queen v. Tolson, 23 Q. B. D. 168, 185, 186 (1859) : "Though this phrase is in common use, I think it most unfortunate, and not only likely to mislead, but actually misleading, on the following grounds. It naturally suggests that, apart from all particular definitions of crimes, such a thing exists as a 'mens rea,' or 'guilty mind,' which is always expressly or by implication involved in every definition. This is obviously not the case, for the mental elements of different crimes differ videly. . . . 
doubt "guilt" in a non-technical sense is frequently present when crimes are committed, but any crime may be and many crimes frequently are committed without it; it is no more necessary to the crime that it be accompanied by such guilt than it is necessary to such guilt that it be accompanied by the crime. Larceny and murder, for example, involve various forms of "mens rea"; but if one steals at great inconvenience and risk to himself, and in obedience to a categorical imperative, to feed a starving child, he commits larceny, and if a physician purposely ends the suffering of an incurable patient who is anxious to die, he commits murder.

To an unlegal mind it suggests that by the law of England no act is a crime which is done from laudable motives, in other words, that immorality is essential to crime."

"The truth is that the maxim about 'mens rea' means no more than that the definition of all or nearly all crimes contains not only an outward and visible element, but a mental element, varying according to the different nature of different crimes. . . . 2 STEPHEN, History of CrimINAL LAW (1883) 95. 